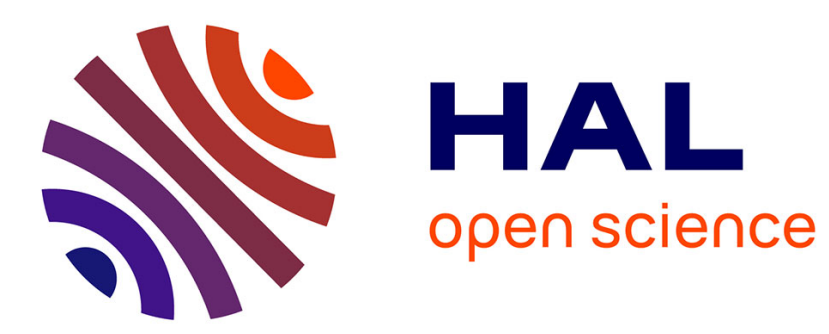

\title{
Political Rescaling and Municipal Cultural Public Policies: A Comparison of France and Québec
}

\author{
Sandra Breux, Jean-Pierre Collin, Emmanuel Négrier
}

\section{To cite this version:}

Sandra Breux, Jean-Pierre Collin, Emmanuel Négrier. Political Rescaling and Municipal Cultural Public Policies: A Comparison of France and Québec. International Journal of Urban and Regional Research, 2007, 31, pp.128 - 145. 10.1111/j.1468-2427.2006.00706.x . hal-01436914

\section{HAL Id: hal-01436914 https://hal.science/hal-01436914}

Submitted on 16 Jan 2017

HAL is a multi-disciplinary open access archive for the deposit and dissemination of scientific research documents, whether they are published or not. The documents may come from teaching and research institutions in France or abroad, or from public or private research centers.
L'archive ouverte pluridisciplinaire HAL, est destinée au dépôt et à la diffusion de documents scientifiques de niveau recherche, publiés ou non, émanant des établissements d'enseignement et de recherche français ou étrangers, des laboratoires publics ou privés. 


\title{
Political Rescaling and Municipal Cultural Public Policies: A Comparison of France and Québec
}

\author{
SANDRA BREUX, JEAN-PIERRE COLLIN and \\ EMMANUEL NÉGRIER
}

\begin{abstract}
Do territories change public policies? This would appear to be a rather unusual research orientation. It is even a reversal of the most commonly accepted approaches to the study of territorial public action, which tend to look at this issue from the opposite perspective, that is, in examining how public policies affect territories. The municipal reforms that have simultaneously occurred in Québec and France since the late 1990s afford an excellent opportunity to consider this inversion of the issues. To do so, we take as our theme culture and municipal cultural policies. We try to define and understand to what extent there exist in Québec and France retroactive links between municipal restructuring and municipal decisions about cultural facilities and activities and, more generally, municipal cultural intervention in the urban milieu. This comparative analysis of the cases of France and Québec focuses on discourse as well as achievements. First, we look at the changes arising from institutional reforms in the supply of cultural activities, budgets devoted to culture, and cultural policies. We then consider culture as a vector in the construction of a new municipal institution and a new municipal territory.
\end{abstract}

Municipal reforms undertaken in all Western democracies at the end of the 1990s bear witness to three major evolutionary developments (Collin, 2004). First, they demonstrate states' willingness to correct this scalar discrepancy. In particular, we notice the creation of policies of territorial reorganization based on the general goal of better 'institutional' recognition of urban areas' functional reality. Second, the phenomenon of globalization has led the nation states to decentralize, notably shifting some powers to the local level (Brenner, 2002; Purcell, 2003). The political emergence of this local level has had two major consequences. In the first place, various reforms concerning municipal restructuring and intercommunality, as well as national reforms, have induced political and civic actors to adjust their practices (frequently designated as 'governance') (see Pierre, 2000; Goldsmith 2001; Jouve, 2003). As underscored by Boudreau and Keil (2004: 1), 'the way in which state actors legitimize their public policies and more generally the process of public decision-making' has changed. Also, this change in political scale follows from the reterritorialization process, fostering the creation of a new political territory. This new territory is, in fact, more of an instrument of public action than a site of political legitimization (Brenner, 2002; Boudreau, 2003). Third, such upheavals encourage a revisiting of the relations between territory and local public policies. Has the political scene been genuinely transformed by the territorial and political coherence supposedly established by municipal reforms, along with political actors' adaptation to such restructuring? Could one stand the assertion of Duran and Thoenig (1996) on its head, and claim that territory represents political sovereignty more 
than ever and that, contrary to previous practices, it encompasses the content, direction, and implementation of public policies? This involves taking the notion of 'territorialization' to heart. So territory becomes one of the major variables of change rather than, as customary, a simple secondary variable or adjustment in the analysis of decentralization or development policies (Benko and Lipietz, 1992).

In Québec, as in France, the plan to grant urban areas their own institutions and thus to address the question of the delicate balance between functional city and institutional city is underway. This 'political invention of the urban area' (Baraize and Négrier, 2001) is not so much reflected in innovative institutional research - since, on the contrary, the classic solutions of mergers on the one hand and intercommunality on the other remain popular - as in the concern to see the urban area emerge as a new player in the public sphere.

We believe it is possible to advance the following hypothesis: at the municipal level, a change in political scale influences public policies. This hypothesis is relevant because various schools of thought dealing with municipal reform have emphasized the territorial issue as secondary to municipal organization. On one hand, reformers, following in Wood's footsteps, have shown that the creation of an extended metropolitan entity allows for a better response to urban problems (Wood, 1961). In the same vein, the new regionalists call for the setting up of cooperative mechanisms, if not institutions, at the broadest regional level (Drier et al., 2001). On the other hand, the public choice school favours municipal fragmentation. According to this theoretical perspective, a juxtaposition of small urban entities constitutes a scale sufficient to solve public problems (Ostrom et al., 1961). The question of territorial size ${ }^{1}$ at the municipal level is, therefore, crucial. Directly and indirectly, the definition of these borders influences public - and private - action.

Furthermore, these territorial limits of municipal entities also determine identity. In addition, the latter will be defined by the number and type of political actors in the equation, as well as encounters with the actual practices of these actors. Following the municipal mergers in Québec, Léveillée and Léonard (2003) stress 'municipal mergers have led to culture shock amongst the various municipal actors. Divergent approaches to administration are emerging'. So might territorial level indirectly affect the very foundations of the political game, in addition to the economy of local public policies? Amongst the responsibilities exercised by the new institutions in both France and Québec are the most strategic aspects of urban government: policies concerning transport, lodging and sustainable development.

The nature of public policies and the subsequent configuration of actors required have been the subject of some research in Canada and Europe (Le Galès, 2002; Andrew, 2003). In Canada, Andrew (2003) stresses the initiatives undertaken in terms of urban security for women in Montréal, Toronto and Ottawa. Furthermore, Collin et al. (2006) revealed existing disparities in both cultural and environmental policy in Canadian cities of less than 200,000 inhabitants: in practice, the political and territorial context of each of the urban entities studied seems to determine the content of public policies. Such observations corroborate the results of various studies published on the topic (Vivre en Ville, 2001).

Along the same lines, in Europe, Le Galès (2002: 215) focuses on cities' innovative capacities to counter their social inequalities: 'In most European countries, they do something other than simply apply national policies. Councillors are subject to daily pressures that mean they attempt, if with difficulty, to coordinate and adapt public policy in collaboration with other groups, since anti-poverty strategies mobilize the associative sector including, for example, humanitarian groups and religious or charitable associations as well as associations combatting exclusion'. A similar observation is made by Jacques de Maillard (2005) on urban security policies.

1 In our research, territory designates the restructured municipal entity, in other words, the new political level created by municipal reorganization. 
Moreover, in a comparative analysis of French and Italian cities, Gilles Pinson (2002) revealed the evolution of urban planning policies that are changing under the effect of metropolization and are witnessing the creation of a new vision of development, bringing together new goals in the areas of quality of life, sustainable development and creativity. For their part, in the course of a comparative analysis of a dozen large North American and Western European cities, Savitch and Kantor (2003: 1003) conclude that 'cities have real alternatives in coping with the effect of globalization' and the capacity to generate a variety of public policies in response.

Beyond these local particularities, whether in Canada or Europe, it is more the financial issue which is a constant. Specifically, finances are at stake in handling policies previously managed by central cities, but also in new forms of fiscal solidarity amongst areas (communes and neighbourhoods) of the metropolis. Thus, we can see that though certain choices tend to maintain inequalities between areas, some are oriented towards a new form of fiscal equalization, while demonstrating innovation in terms of those policies favouring fiscal conservatism (Clark and Inglehart, 1998). In contrast, others are creating a new urban solidarity (Négrier, 2005b). This question of urban inequalities is also at the heart of issues raised by Sellers and Hoffman-Martinot (2006) on the metropolization of political behaviour in major urban areas.

While numerous theoretical reflections on these recent political and territorial upheavals exist, there are considerably fewer validating or empirical studies. Generally only the most exemplary or largest urban entities have been analysed, whether in Canada (Andrew, 2003; Boudreau, 2003) or Europe (Jouve and Lefèvre, 2002; Le Galès, 2002; Heinelt and Kübler, 2005; Pinson, 2005). Furthermore, Québec and France have received scant attention in these studies: little research compares urban entities on the two continents, and comparisons between local levels in France and Québec are few and far between. Though Keil et al. (2006) question the relevance of a comparative analysis of urban studies, notably because of the disparities encountered, these authors nonetheless draw attention to the wealth of information opened up by such research.

Faced with these deficiencies, our goal is to demonstrate that a change in policy level directly affects the content and implementation of public policies. More precisely, this objective can be achieved, on the one hand, through looking at the territorial recomposition currently underway and the contents of a public policy, in particular that of cultural public policy, and, on the other, through comparing the French and Québec cases.

Three principal reasons underlie the choice of a comparison between France and Québec. First, there is the quasi-simultaneity of the implementation of their municipal reforms (1999 for France, 2002 for Québec) along with their divergent forms (intercommunal cooperation in France and mergers in Québec). Moreover, these two reforms devoted particular attention to the conversion of urban areas, into integrated cities in Québec and communities of urban areas in France. Finally, municipal reorganization was in both cases more than an enlargement of the central or principal city's territory. So, in Québec, they wished to redraw the municipal pattern of urban areas with a multi-layered reform: a reorganization of local municipalities and a supramunicipal level (county regional municipalities and urban communities), a renewal of political systems and administrative structures, the establishment of institutional innovations such as boroughs, and the redefinition of municipal mandates. In France, this reform changes not only the scope of the cooperative territories, but also the political balance between communes, départements and regions, in a context of decentralization.

Our comparison could appear unbalanced, in choosing a federal state and a unitary one, and in comparing two different levels, that of the central state on one side, and a province on the other. In reality, these differences are secondary here: the basis of comparison are cities and their relation to their immediate territorial environment, on one hand, and relations between these areas and the higher level that possesses most of the constituent power, on the other, the state in France and the province in Québec. While we will observe that the differences are sometimes significant, this in no way negates the comparability of urban issues and the way in which territorialization of 
public policies should be analysed. Thus, in Québec, there was a wish to restructure the municipal framework of urban areas with reform at several levels: a grouping of local municipalities and of communities at the supra-municipal level (regional county municipalities and urban communities), a massive reorganization of political systems and administrative structures, the implementation of institutional innovations as in the case of boroughs, and a redefinition and sharing of municipal missions. In France, this reform not only modifies the range of cooperative territories, but also transforms the balance of policies amongst communes, départements and regions, within the context of decentralization.

The cultural sector, as well, was chosen as a result of three factors. Above all, it can be explained by the political stakes, both national and local, involved in the cultural sphere. Thus, Bassett et al. (2005) observe that, in the United Kingdom, the cultural sector has become particularly fertile ground for the formulation of new public policies in response to issues of cities' competitiveness and cohesion, not only at the national level but also at the level of regions and cities. Culture is a component of territorial identity and, in periods of reorganization, can help bring the new territorial reality into existence (Négrier, 2005a). Furthermore, in France as well as Québec, cultural services and facilities are an optional domain for communities of urban areas and cities, respectively. Consequently, in both contexts, culture has above all been considered as a national (provincial) area of responsibility and if it has been in part remote controlled by the central government, municipal involvement has been conditioned by specific municipal contexts and dynamics. Finally, both in France and Québec, the relationships between municipal reform and political culture are of considerable interest, and some researchers have raised the need to examine how the newly created municipal territory modifies the practices, direction and content of local public cultural activity (Saint-Pierre and Coutard, 2002). In addition, our choice is related to the opportunity to make use of previous studies, in France and in Québec, analysing the impact of municipal reforms on local cultural action (Breux, 2004; Négrier, 2004b).

Initial analyses, therefore, suggest the existence of a certain tendency towards convergence of processes as a function of demographic levels (more than 100,000 residents in Québec, and more than 80,000 residents in France). However, this tendency is counteracted in both cases by decisions made based on the various territories, as well as the manner in which the strategies implemented are dependent on territorial configurations.

A comparison of France and Québec will allow us to better understand the impact of territory on public policies. Indeed, these two states display different cultural and political contexts. The divergence of municipal reforms adopted will highlight the obvious extent to which territorial (intranational) differences affect the nature of cultural public policies. In fact, if our initial hypothesis is correct, the cultural policies of France and Québec should reveal their distinctive political and identity contexts, at the national level. Thus, France favours a cooperative intercommunal model based on voluntarism, whereas Québec subscribes to a model of state voluntarism, through municipal mergers decided upon and imposed by the provincial level. Consequently, these two varieties of reform create distinct territorial formulae. It is therefore interesting to determine the impact of the latter on public policies. To that end, the samples employed for these two studies (France and Québec) will be re-examined here.

In France, the territories under consideration are a series of communities of urban areas, ${ }^{2}$ representative of French territorial diversity. For Québec, the cities of Montréal, Québec, Trois-Rivières, Sherbrooke, Longueuil, Gatineau, Saguenay and Lévis were selected. These cities were chosen because of the size of their population, more than 100,000 residents, and the date of their restructuring, 2002.

2 Amiens, Angers, Angoulême, Annecy, Béziers, Caen, Clermont-Ferrand, Dijon, Le Havre, Lorient, Lyon, Montbéliard, Montpellier, Metz, Nancy, Nantes, Nîmes, Orléans, Perpignan, Rennes, La Rochelle and Rodez. 
This hypothesis will be tested in three stages. First, a combined analysis of municipal reforms and the cultural sector's evolution in France and Québec will allow us to establish the nature of both societies' political and cultural contexts and to appreciate the similarities and differences between their institutional and political practices. Next, we will examine the impact of municipal reform on the conduct of cultural public policies. Finally, we will raise the question of the direct or indirect influence of changes in political scale on the form and substance of these public policies.

\section{From common objectives to territorial specificities}

During the 1990s, international upheavals led all Western democracies to reform their public affairs management. While this adjustment conceals very different realities amongst these countries, it also highlights the presence of comparable processes.

France adopted a rather voluntarist policy from 1959 to the beginning of the 1970 s. While inter-municipal cooperation increased during this period, the reduction in the number of municipalities was a failure. In 1971, the government chose the merger model, in a country with a very large number of communes. The results were extremely modest: 775 mergers (of 1,901 communes) took place. The resistance of local elected officials was the main cause of this failure.

From 1971 to 1992 , there were successive attempts to engineer a reduction in the number of municipalities, a reform of state apparatus, and an adaptation to new economic realities. These debates did not involve returning to the merger formula, but rather focused on a strengthening of intercommunality, whose progressive and haphazard development was covered by three main pieces of legislation in the 1990s. First, the law of 6 February 1992, known as the Republic Territorial Administration Act (Loi 'ATR' Administration Territoriale République), started the process by setting up communities of communes and of cities. The principal objective was to foster territorial cohesion, with one particular institution designated to manage it: the Intercommunal Cooperation Institution (L'Établissement Public de Coopération Intercommunale $(E P C I)$. This law transfers powers, articulating an initial compromise, given the political impossibility of merging communes (Piraux, 1997: 19). The effects of this new framework were modest and widely contested. Approximately a thousand institutions were created and 'reveal considerable diversity in the tasks, contents and legal systems of these new organizations' (Négrier, 2004a: 4). Secondly the Pasqua Act (1995), known as the Orientation for Planning and Territorial Development Act (Loi du 4 février 1995 d'orientation pour L'aménagement et le développement du territoire), initiated the creation of a new body, that of le Pays (a subregional area of voluntary cooperation). This law gave rise to the concept of 'project territories', taken up again in a later law, the Voynet Act in 1999. Finally, the Chevènement Act (1999), known as the Reinforcement and Simplification of Intercommunal Cooperation Act (Loidu 12 juillet 1995 relative au renforcement et à la simplification de la coopération intercommunale), creates communities of urban areas for urban centres and their peripheries (from 50,000 to 500,000 residents), urban communities for large cities (more than 500,000 residents) and communities of rural communes, the urban periphery and small cities (with less than 50,000 residents). The Chevènement Act constitutes a form of rationalization of cooperation, whose substantive nature and results demonstrate that it is the most effective form of French intercommunality (Kerrouche, 2005). The principles underlying French intercommunality are thus the principles of solidarity, cooperation, planning and decentralization. In all, in 2004, there are more than 2,461 institutions, affecting 31,424 communes and some 50.8 million residents (Négrier, 2004a: 11). The statistical success of this operation is the mirror image of the failure, 33 years previously, of the law to merge communes.

In Québec, the inadequacies of the municipal system were made evident throughout the 1960s. In 1965, the government initiated a strategy of voluntary mergers stated to 
last until the end of the 1990s. Throughout this period, the necessity to consolidate the urban areas was emphasized (Collin, 2002). However, over 20 years the results were extremely modest, with the number of municipalities in 23 urban census areas declining from 300 to approximately 270.

At the start of the 1990s, the City of Montréal underwent a serious fiscal crisis. A task force on Montréal and the surrounding region was created which, in its final report in 1993, proposed an in-depth revision of regional municipal organization and substantial changes in provincial policies, particularly in the area of municipal taxation (Task Force on Greater Montréal, 1993). The report did not broach the issue of municipal mergers but advanced the adoption of an overall organizational concept of the city-region, along the lines of the City of Montréal position paper. The central cities of other metropolitan regions followed in the footsteps of the City of Montréal, calling for municipal organizational reform in urban areas through the Table of Central Cities, set up by the Québec Municipal Affairs Department, and the Caucus of Six Major Central Cities, hosted by the City of Québec. Meanwhile, in 1996, the province submitted a Policy of Local Community Consolidation and, in 1997, a New Municipal Pact. Municipal mergers, strengthening of supra-municipal authorities and inter-municipal cooperation, decentralization and municipal fiscal reform were consequently put on the agenda.

The result of these debates appeared between 1999 and 2002 in two central documents, the Bédard Report, entitled Pact 2000 (CNFFL, 1999) and Minister Louise Harel's White Paper, entitled Changing the Ways to Better Serve the Public (MAMM, 2000). The report of the National Committee on Finance and Local Taxation underscores the need to re-examine municipal structures. This constitutes a decisive step because no study had ever gone as far in its conclusions. Moreover, such an observation led the cities of Montréal and Québec to develop their own proposal, based mainly on municipal mergers. Subsequently, the White Paper of the Municipal Affairs Department committed the government to an intensive period of reforms, with the adoption in the following months of the plans outlined in Act 124 (respecting municipal territorial organization) and Act 170 (concerning the reform of municipal territorial organization in the Montréal, Québec and Outaouais metropolitan regions).

These laws had four major consequences (Latendresse, 2004). The number of municipalities was reduced and eight cities of more than 100,000 residents were created. These new cities also absorbed the supra-municipal authorities (urban communities and regional county municipalities). ${ }^{3}$ New decentralized structures called boroughs were established to run local services (Collin and Robertson, 2005). In Montréal and Québec, metropolitan communities were created, responsible for regional planning for the metropolitan census area. Finally, the reform introduced urban area taxation (Belley, 2004: 6-7). More than ever, Québec municipal reform emphasized the principle according to which municipalities were 'creatures' of the provinces and authorities subject to provincial political games (Belley, 2004: 10). In three years, from 2000 to 2003, the number of municipalities fell from 1,332 to 1,119 . Overall, some 60 municipalities were restructured. ${ }^{4}$ These reductions particularly affected the municipal entities composed of between 500 and 999 residents, as well as those with 10,000 to 24,999 residents.

Since the 1960s, it seems that France and Québec have pursued opposite paths with regard to municipal restructuring, despite similar objectives. France started the wave of municipal reorganization with a strategy of forced mergers (1971) while, in the same period, Québec was opting for 'voluntary mergers'. In the 1990s, France implemented a strategy of voluntary inter-municipal cooperation, whereas Québec chose 'forced' mergers. ${ }^{5}$ However, this divergence is attenuated when one considers the similarity of their objectives (see Table 1).

3 This is the case for Montréal, Québec, Longueuil, Gatineau, Sherbrooke, Saguenay, Trois-Rivières and Lévis.

4 See the website of Ministère des Affaires Municipales et des Régions (http://www.mamr.gouv.qc.ca/).

5 Upon the Liberal Party arrival in office, these forced mergers led to referenda to consult citizens on the 2001 and 2002 municipal reorganization. In June 2004, a majority of electors in 21 former cities 
Table 1 Comparison of organizational principles of municipal reforms in urban areas in France and Québec

\begin{tabular}{lll} 
Description & France & Québec \\
\hline Laws & $\begin{array}{l}\text { 6 February 1992 } \\
\text { 4 February 1995 } \\
\text { 12 July 1999 }\end{array}$ & $\begin{array}{l}\text { Act 124 of June 2001 } \\
\text { Act 170 of December 2001 }\end{array}$ \\
\hline Principles & $\begin{array}{l}\text { Voluntarism based on a specific } \\
\text { area, according to principles of } \\
\text { subsidiarity }\end{array}$ & $\begin{array}{l}\text { Municipalities are 'creatures' of the } \\
\text { provinces }\end{array}$ \\
\hline $\begin{array}{l}\text { Municipalities' margin of } \\
\text { manoeuvre with regard }\end{array}$ & $\begin{array}{l}\text { Municipalities are free to join } \\
\text { together or not, and may choose } \\
\text { to municipal reform }\end{array}$ & $\begin{array}{l}\text { Municipal reform is provincial. The } \\
\text { municipalities do not have the right } \\
\text { to decide whether or not to merge }\end{array}$ \\
\hline Forms & $\begin{array}{l}\text { Community of urban areas, } \\
\text { communities of communes, and } \\
\text { urban communities }\end{array}$ & $\begin{array}{l}\text { Mergers of municipalities and a new } \\
\text { category of cities - MRC (regional } \\
\text { county municipalities). Creation of } \\
\text { metropolitan communities }\end{array}$ \\
\hline Taxation & $\begin{array}{l}\text { TPU (single professional tax) plus } \\
\text { state block grant to the local } \\
\text { sector }\end{array}$ & $\begin{array}{l}\text { New fiscal arrangement between } \\
\text { Québec and the municipalities plus } \\
\text { some taxation measures for the } \\
\text { urban area }\end{array}$ \\
\hline $\begin{array}{l}\text { Municipal cultural } \\
\text { financing }\end{array}$ & $\begin{array}{l}\text { Historically, municipal financing is } \\
\text { the highest compared with other } \\
\text { governmental financing levels }\end{array}$ & $\begin{array}{l}\text { Meagre in comparison to sums } \\
\text { granted by federal and provincial } \\
\text { governments to their own cultural } \\
\text { sectors }\end{array}$ \\
\hline
\end{tabular}

The pursuit of common objectives also involves the cultural domain, both at the municipal and urban community levels. In France, intercommunality is reshaping territories and, indeed, modifying their representation, symbols and traditional stakes, in all of which culture plays an essential role (Faure and Négrier, 2001). In Québec, Diane Saint-Pierre and Jérôme Coutard (2002: 1) emphasize 'that this municipal reorganization will have important repercussions on the cultural development of the cities of Québec'. Political rescaling particularly affected culture because, over the same period, the cultural sector itself underwent a process of territorialization. In both cases, this was a form of cultural decentralization, through the transfer of powers from the national level (in France) and provincial level (in Québec) to local bodies. Yet this is also a form of cultural devolution, which is reflected in a transfer of responsibilities for these administrative policies from central and ministerial control to the territorial level (regional delegations or management).

In France, as in Québec, culture has always been a highly political affair. In France, the creation of a Ministry of Culture by André Malraux in 1959, well before the widespread establishment of ministries of culture in other European countries, exemplified France's policy originality. The territorial dimension of France's cultural policy is one aspect of the country's singularity. In 1979, Regional Offices of Cultural Affairs (Directions Régionales des Affaires Culturelles - DRACs) were created. These represent the state at the regional level and their official goal is to apply national policy in the regions, to oversee the coherence of local activities, and to advise and support regional bodies. So public cultural activity is most developed at the municipal level and 


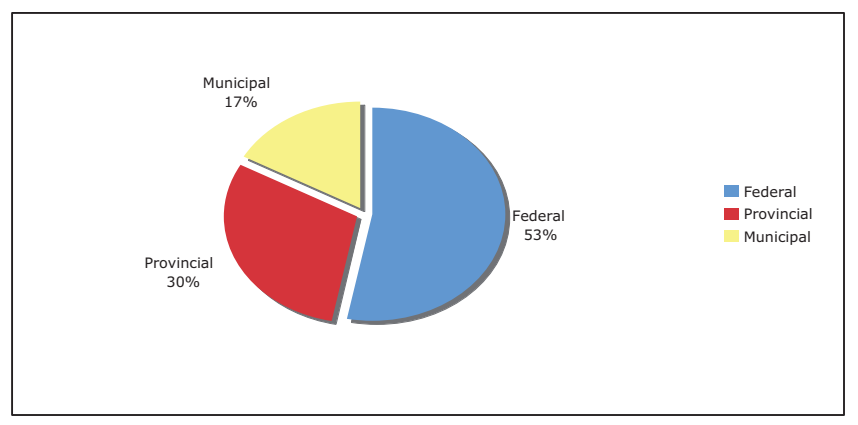

Figure 1 Québec: each level of government's share of total cultural expenditures (all sectors combined), 1999-2000 (source: graph produced according to data from the Research and Statistics Directorate, 2004: 2)

in the cities. This explains why the emergence of intercommunality is of such obvious importance, in terms of allocation of powers and the repositioning of actors and their strategies.

In Québec, the first Cultural Affairs Department was created in 1961. In 1978, the latter was replaced by a ministerial superstructure, joining departments with cultural vocations, with the explicit intention of constituting a counterbalance to the supremacy acquired over the years by the federal government. Indeed, Québec's culture is associated with the concept of sovereignty and sparks most of the confrontations between the federal and provincial levels. However, this super-ministry was abolished in 1982. The beginning of the 1990s saw the publication of a number of studies (including the Coupet Report in 1990, and the Arpin Report in 1991), highlighting cracks in the system and, above all, the adoption in 1992 of a provincial cultural policy with three principal consequences. The first was the creation of a Ministry of Culture, replacing the Cultural Affairs Department; the second was the creation of an Arts Council $^{6}$ at the Québec level; and the final effect was a determination to devolve cultural powers towards the local authorities. As in France, local entities would become major cultural players. Their activities were in addition to those of the cultural promotion offices and the regional cultural councils, evidence of the ministry's dispersal of its functions to the administrative regional level since 1978. Moreover, from the 1960s to today, the expanding role of culture has been quite striking, particularly in financial terms. Cultural budgets have increased dramatically in France (Négrier, 2004b: 6) and in Québec (Research and Statistics Directorate, 2004: 1).

Beyond these similar tendencies, territorial political organizations of France and Québec differ. While in France, the municipal sector is historically the one providing the most support to culture, in Québec, the municipal level provides the least financing to this sector (see Figures 1 and 2). Similarly, resources are allocated differently. So, cultural reality is not identical on both sides of the Atlantic (see Table 1).

In the cultural sphere, therefore, the French and Québec examples illustrate similar processes, revealing both common objectives and distinctive practices. In both systems under analysis, the groundwork has been laid for progressive decentralization in favour of local bodies. Intercommunality and municipal mergers have served to gently accelerate cultural sector reform. 


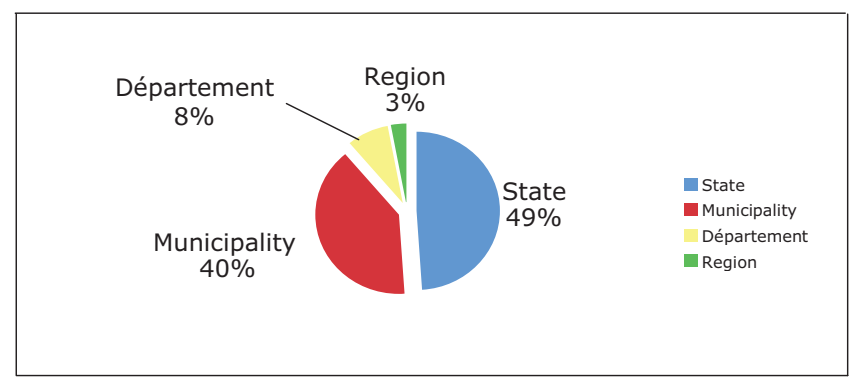

Figure 2 France: each level of government's share of total cultural expenditures (all sectors combined), 1999-2000 (source: Négrier, 2004a).

\section{Towards cultural territorialization}

The description of municipal reform and the local cultural sector's evolution have underscored converging objectives in France and Québec. This convergence of goals attenuates French and Québec particularities. Still, the question remains as to whether municipal reform, with similar objectives, affects municipalities' cultural strategies in these two contexts. Or, on a broader scale, what are the links between municipal reform and political culture? May one conclude that consolidation of municipalities changes municipal cultural policy? Is such a question equally valid in the case of a merged city in Québec and a French community of urban areas?

Despite the new cities' fresh responsibilities, in both France and Québec, at first glance, these cultural powers appear to be 'empty shells'. This is due to their relative imprecision and their limited nature.

In France, this is a case of communities of cities overseeing 'construction, development, maintenance, and cultural and sports facilities management'. The 'management of cultural and sporting facilities' is nowhere defined and allows the urban areas to choose their degree of involvement. Thus, some will integrate cultural policy at the level of the urban area, maximizing community cooperation. On the other hand, other urban areas will choose lesser powers, limiting themselves to specific operations. Therefore, municipalities employ and adapt the margin of manoeuvre resulting from the vague cultural authority granted to communities of urban areas.

In Québec, Act 170 mentions two particular areas for which merged cities are responsible, the adoption of an economic, cultural and social development plan, and the possibility or obligation (depending on the context) of establishing an arts council. The adoption of an economic, cultural and social development plan is not actually a new domain. It is rather an institutionalization of a previous practice, and, more precisely, a harmonization of practices amongst the merged cities. As in France, the issue of the creation of an arts council highlights the cities' margin of manoeuvre. Indeed, with the exceptions of the cities of Québec and Montréal, the choice of the other cities conceals different strategies. A study of institutional decrees reveals that the charters of Longueuil, Gatineau, Lévis and Saguenay include the possibility of creating an arts council. Nonetheless, only the cities of Longueuil and Saguenay chose to establish such a structure. During public consultations, the City of Gatineau decided on the creation of an Arts, Culture and Heritage Committee. This committee is a quasi arts council adapted to the Gatineau reality, with the aim of making the transition towards any eventual arts council. Meanwhile, the cities of Sherbrooke and Trois-Rivières rejected this cultural responsibility in favour of, respectively, a cultural board and a cultural centre (Breux, 2004: 15).

These examples illustrate the specific steps taken by French and Québec cities. Thus, at first, municipal reform seems to have impacted municipal cultural practices, due to 
the cities' margin of manoeuvre, which they find useful. Specifically, it is also possible to see the effect of municipal reorganization on the goals pursued by way of examination of short-term cultural policies.

Municipal restructuring has also been a means of reinforcing acquired rights, particularly of a budgetary nature. However, in both cases, there were serious deliberations about the new organization (issues of facilities networks, and management of the territory, but also coordination between the municipal and urban level). Generally, it is a question of adapting and expanding a political model, up to now conceived by former central city authorities. Making the creation of such a council mandatory guaranteed its continued existence, even in the case of an eventual political victory of a party opposed to such an institution (Breux, 2004: 18). This is certainly true in terms of establishing cultural policies. It is even worth noting that many former municipalities, now components of merged cities, had municipal cultural policies.

In addition, in both France and Québec, municipal reorganization has increased resources allocated to the municipal cultural sector, although the forms of the increase vary considerably. In France, this meant a tax increase specified in the Chevènement Act, ${ }^{7}$ while in Québec it meant a general tendency to raise cultural spending, as evidenced by a shift in expenditures (from operating to capital expenditures) and a growth in the number (not necessarily the amount) of subsidies allocated to the local cultural sector.

In France, it is worth re-examining the provisions of the Chevènement Act. This law has also put in place a new tax, collected by the urban area, the Single Professional Tax (Taxe Professionelle Unique). The urban area receives it, instead of the member communes. In addition, this tax is accompanied by a state block grant which, depending on the situation, may constitute a doubling of the overall level of the state's grant towards the metropolitan institution, starting in the first year. Therefore, the Chevènement Act has created a genuine financial incentive strategy. This financial incentive has often been relatively determinant in urban areas' decisions to opt for the assumption of cultural responsibility, despite resistance from both elected officials and professionals, with those responsible for cultural facilities, for example, wishing to preserve their independence. This financial incentive has often been relatively determinant in metropolitan units' choice of cultural responsibility, despite two types of resistance. The first is that of elected municipal officials who wish to maintain some independent decision-making authority with regard to policies with which they identify more strongly. The more optional the field, the stronger the expression of political will, and the more difficult it is to share this responsibility with other elected officials. This is precisely the case with cultural activity and its strategies of public differentiation through facilities such as theatres, media centres or museums, or events such as festivals, fairs and holidays (Faure and Négrier, 2001). But the second resistance, less discussed, is of equal importance. This is the resistance of professionals in charge of the cultural facilities who view any territorial transfer as a threat to the stability of their strategic environment (their public policy community) or their artistic and cultural project (Négrier, 2006). However, as we will see in the following section, these constraints vary in importance according to the territory. While, in one instance, they represent an obstacle to any transfer, elsewhere they may be a significant element in transfer negotiations. This shows the value of differentiation analysis of territories.

In Québec, there is no question of increased tax revenue. The fiscal pact only permits elected officials to raise property taxes, and, unlike France, there is no intersection with state financing. Certainly the provincial government encourages municipalities to establish these policies, but it does not pressure them to do so. Rather the provincial government supports municipalities that wish to come up with such policies. Within this

7 Indeed, the creation of a community entails increased transfers from the state, which are enhanced by the effective transfer of facilities management to the community level. Transferring cultural facilities, therefore, 'yields benefits' for the new institution. 
framework, the creation of a cultural policy is a necessary condition for the signing of an agreement with the ministry (Breux, 2004: 13). Thus, this constitutes an indirect financial incentive. Indeed, more precisely, analysis reveals the cultural budgets of new cities tend to be higher than those of former cities. This is particularly true of capital expenditures, and implicitly reflects the desire to consolidate existing structures before developing them. Thus, increased operating expenses are likely in the future. Finally, and very significantly, an increase in municipal subsidies to cultural organizations and artists is noted. This varies in kind. Thus, some cities have raised the amount of subsidies allocated, whereas others have increased the number of organizations or artists who benefit.

Furthermore, analysis of the urban areas' and merged cities' practices underscores a change in principal partners. The considerable evolution of the cultural sector, which has become more professional and has developed considerably in terms of partnerships, is worth noting. In France, as in Québec, the state is present through the Ministry of Culture, which is institutionally and historically a predominant partner. Yet the practices of French and Québec cities reveal a new reality. The national or provincial government is not the only partner, since new players have emerged: the cultural milieu itself, professional or amateur; the various levels of public action, from the commune to the federal level, including urban and metropolitan institutions, regional institutions, etc.

Finally, and this is peculiar to Québec, citizens have helped define cultural policy through public consultations. Henceforth, the merged cities are dealing with larger populations, with greater and more diverse needs and expectations. Thus, the collaborative definition and establishment of a new cultural policy are justified by both concern with reflecting the reality of the entire new territory, and recognition of the internal diversity of each former municipality. In France, a single institutionalized form of political representation, elected local officials, are usually responsible for this process.

Therefore, an examination of French and Québec situations underscores similar consequences despite contexts which differ (see Table 2). It is possible to contend that, through municipal reform, territory affects the implementation of cultural policy. Indeed, regardless of the nature of municipal reform (cooperation or merger), a territorial change leads to similar results. More specifically, we can discern four similar consequences of the impact of municipal reorganization on French and Québec cultural sectors. First, cultural responsibility linked to local reforms, while different in substance in France and Québec, is both summary and imprecise. Therefore, it leaves municipalities a meaningful margin for manoeuvre. Reorganization has also led cities to develop fresh strategies in adopting a cultural policy, particularly in order to preserve acquired rights. Furthermore, municipal cooperation fosters new sources of revenue, which help the cultural sector evolve and, sometimes, expand. Finally, municipalities' partners have shifted. The cultural milieu has become a paramount partner, more important than the higher political level.

Therefore, municipal reform has a whole gamut of effects on the conditions of implementing cultural activity. These effects concern the sociology of the actors, the balance of power, and the ability to act. More generally, they bear witness to the territorialization of cultural policies. In that respect, territory already appears to be a variable to consider in a sectoral policy such as that of culture. However, we will now show that it is a differentiating factor in the way in which territorialization operates in various territorial configurations.

\section{Territorialization and policy differentiation}

The first part of this analysis has shown that culture plays a symbolic and strategic role at the provincial and national level. This is equally obvious at the local level. Indeed, culture is often the veritable preserve of elected officials. It is a domain 
Table 2 Comparison of municipal reforms' impact on the local cultural sector in France and Québec

\begin{tabular}{|c|c|c|}
\hline Results & France & Québec \\
\hline $\begin{array}{l}\text { Nature and number of newly } \\
\text { created institutions }\end{array}$ & $\begin{array}{l}155 \text { communities of urban areas } \\
14 \text { urban communities } \\
2,286 \text { communities of communes }\end{array}$ & $\begin{array}{l}60 \text { mergers, including the creation } \\
\text { of eight cities of more than } \\
100,000 \text { residents and two } \\
\text { metropolitan communities }\end{array}$ \\
\hline $\begin{array}{l}\text { Status of cultural } \\
\text { responsibility }\end{array}$ & Optional & Mandatory and optional \\
\hline $\begin{array}{l}\text { Nature of cultural } \\
\text { responsibility }\end{array}$ & $\begin{array}{l}\text { Construction, planning, } \\
\text { maintenance, cultural and sports } \\
\text { facilities management }\end{array}$ & $\begin{array}{l}\text { (1) Economic, cultural and social } \\
\text { development plan (mandatory) } \\
\text { (2) Choice as to whether to } \\
\text { establish an arts council } \\
\text { (optional) }\end{array}$ \\
\hline $\begin{array}{l}\text { Characteristics of cultural } \\
\text { responsibility }\end{array}$ & $\begin{array}{l}\text { Summary cultural responsibility } \\
\text { Significant margin of manoeuvre }\end{array}$ & \\
\hline Cultural responsibility & $\begin{array}{l}77 \% \text { of communities of urban } \\
\text { areas chose cultural responsibility }\end{array}$ & $\begin{array}{l}100 \% \text { of eight cities have tabled or } \\
\text { adopted a cultural policy }\end{array}$ \\
\hline & & $\begin{array}{l}\text { Three have opted to create an arts } \\
\text { council. The other five have } \\
\text { created an equivalent body }\end{array}$ \\
\hline Municipal cultural financing & Rising (due to taxation) & $\begin{array}{l}\text { Rising (due to an agreement with } \\
\text { the provinces and sharing of } \\
\text { subsidies in the new territory) }\end{array}$ \\
\hline $\begin{array}{l}\text { Changes to the cultural } \\
\text { sector wrought by } \\
\text { territorial reform }\end{array}$ & \multicolumn{2}{|c|}{$\begin{array}{l}\text { Local cultural independence vis-à-vis the national/provincial level } \\
\text { Widening of the definition of culture } \\
\text { Appropriation of culture by elected officials } \\
\text { Affirmation of territory and identity } \\
\text { Shifting of partners } \\
\text { Guarantee of acquired rights }\end{array}$} \\
\hline
\end{tabular}

which, for reasons of image and independence, they do not readily share (Thuriot, 1997: 74).

In France, this desire for independence can be discerned on the part of both elected officials and professionals in the cultural field. The political resistance of certain elected officials remains strong. In some way, the issue of transferring cultural policies or facilities still raises tensions on a number of fronts: the economic front, the political front, the professional front and the sociological front.

In France, the reality is that these tensions are not resolved in the same way, according to the wishes of the territories. There is well and truly a territorial differentiation of urban and metropolitan cultural policies, which is related to three distinct and interdependent factors: institutional constraints, territorial cultural policy and political leadership. In Québec, the territorial structure of interaction among actors results in conflicts between the former suburban municipalities and the central city.

Moreover, intercommunality and municipal mergers necessitated a revision of the definition of culture. This revision essentially bore on the distinction to be made between the amateur and professional worlds. So the solution to this challenge varies as a function of the particular situation. The definition of culture in certain municipalities was generally based on one of these two worlds more than the other, depending on the scope and history of the specific cultural environment. Municipal reforms seem even to exacerbate this divergence. 
Thus, culture is also an issue at the local level, and is the focus of either relatively fragile consensus or polarization. Yet there is one consistent finding: a varying but clear enthusiasm in many communities of urban areas for control over the cultural sphere (France) or the implementation of cultural policies (Québec). Given culture's political and strategic weight, this is a surprising choice. Thus, in France, more than two-thirds of communities of urban areas chose the cultural option. In Québec, culture was one of the new cities' first areas of intervention and achievement. So, the eight cities of our sample either tabled or adopted a cultural policy shortly after the city's reorganization. In both societies, this cultural responsibility was not imposed. It was optional in France, and, similarly, in Québec, a city may choose to develop a cultural policy. How do we explain this finding?

The response may be found in the nature of France's cultural powers and Québec's cultural policies. The territories of restructured cities set the tone for cultural powers and policies. Indeed, their nature is determined by a territory's identity. The affirmation of territorial identity is apparent through the myriad of definitions conferred on culture. The French concept of 'cultural facilities' allows for a considerable margin of manoeuvre, of which the cities take advantage. There is a varying degree of personalization and appropriation of cultural policy, depending on the city. The diversity of names adopted and the very fact that they have specific names reveal the desire to convey a certain image of culture. Each restructured city, whether in France or Québec, promotes its particular identity. In both France and Québec, there is no harmonization of the content of municipal cultural policies.

Affirmation of cities' identities is even more characterized by a new concern about the relationship to cultural policies of other institutional levels: national, provincial or departmental. This fosters a new dialectic in centre-periphery relationships, with fundamental differences emerging on issues of form (for example, the struggles between territories about power sharing, particularly delicate in France between urban areas and départements), and on what a cultural policy 'must be' (Négrier, 2004b: 9). In Québec, the cities' cultural policies are more precise than the provincial policy of 1992 in two ways. The principles underlying cultural policies are more numerous, and they are more detailed. Furthermore, their definition is more explicit than that of the province. Often, cities' cultural policies seem more avant-garde. This diverging viewpoint is even more surprising since cities are supposed to be working in tandem with the national or provincial level.

Thus, cultural policy represents a way for a territory to assert its identity. This emphasis on identity explains the trend to assume cultural responsibility or adopt cultural policies shortly after municipal reorganization. The identity of the new territory is delineated, recognized and set in competition with neighbouring cities. This serves to legitimize, on one hand, the new territorial configuration, and on the other hand, its current leadership. The example of the community of the urban area of Amiens underscores this process as a result of the multiplicity of political labels within the city. Likewise, the Mayor of Montréal's decision to unfreeze the Arts Council budget, unchanged for 10 years, highlights the importance of such a process.

These findings draw attention to municipal territories' enhanced autonomy, whether in France or Québec (see Table 3). Through the cultural sector, we witness the reformed territories' desire to express themselves. Thus, there is a 'territorialization' of cultural policies. In fact, the territory dictates cultural policies, in their intensity, content and system of reference. This 'territorialization' expresses the advent of a new process, which makes territory a central actor in cultural policies today. This process fosters an original form of decentralization. More of a grass-roots initiative than one imposed by government (regardless of incentives or constraints), it is at the same time growing more diverse. Elected local officials have appropriated for themselves a territorial reform to which many were opposed at first glance. At the same time, they are placed in a position of growing interdependence, among themselves and professional and amateur cultural milieus, institutions from other territorial levels, and state administrations. 
Table 3 The impact of territorial reorganization on French and Québec cultural sectors

\begin{tabular}{lll}
$\begin{array}{l}\text { Nature of changes } \\
\begin{array}{l}\text { Independence of local } \\
\text { cultural level vis-à-vis } \\
\text { the national/provincial } \\
\text { level }\end{array}\end{array}$ & $\begin{array}{l}\text { Discrepancies or opposition to the } \\
\text { 'cultural excellence' model }\end{array}$ & $\begin{array}{l}\text { Surpassing provincial cultural policy } \\
\text { and rejection of the provincial 'arts } \\
\text { council' model }\end{array}$ \\
\hline $\begin{array}{l}\text { Broadening of the } \\
\text { definition of culture }\end{array}$ & $\begin{array}{l}\text { Polarization of recreational } \\
\text { culture and the professional } \\
\text { milieu }\end{array}$ & $\begin{array}{l}\text { Complementarity: creation and } \\
\text { expansion of the concept of cultural } \\
\text { recreation }\end{array}$ \\
\hline $\begin{array}{ll}\text { Affirmation of identity } \\
\text { Reinforced. Particular to each city, }\end{array}$ & $\begin{array}{l}\text { Reinforced by the frequency of } \\
\text { underlying principles of each of the } \\
\text { cultural policies bearing on the }\end{array}$ \\
& $\begin{array}{l}\text { culturally specific domain (e.g. } \\
\text { archaeology) }\end{array}$ & $\begin{array}{l}\text { theme of the city's identity and } \\
\text { recognition of its unique culture. }\end{array}$ \\
\hline $\begin{array}{l}\text { Appropriation of the } \\
\text { culture by elected } \\
\text { officials }\end{array}$ & $\begin{array}{l}\text { (1) Imposition of the cultural } \\
\text { model of the central city } \\
\text { (2) Culture is a political } \\
\text { instrument to legitimize the } \\
\text { leadership team in place }\end{array}$ & $\begin{array}{l}\text { Cultural initiative of the leadership } \\
\text { team }\end{array}$ \\
\hline $\begin{array}{l}\text { Guarantee of acquired } \\
\text { rights }\end{array}$ & $\begin{array}{l}\text { Imposition of the central city's } \\
\text { cultural model }\end{array}$ & $\begin{array}{l}\text { Former municipalities' cultural policies } \\
\text { taken into account in their entirety }\end{array}$ \\
\hline $\begin{array}{l}\text { Shifting partnerships } \\
\text { Cultural milieu }\end{array}$ & $\begin{array}{l}\text { Cultural milieu } \\
\text { Population }\end{array}$ \\
\hline
\end{tabular}

\section{Conclusion}

Do changes in political scale affect public policies? Comparison of the impacts of municipal reform in both France and Québec has allowed us to respond to this question in the affirmative, though it is still wise to interpret these results with caution, for two reasons. The first is that here we are analysing changes that are currently underway. Some of this impact is reflected in actual content or real processes, while some is still at the level of talk. Therefore, we should accept the hypothesis that these changes could be very different in the medium term when eventually implemented. The second reason for caution relates to the level of impact. We have observed these modifications amongst networks of actors, in the breadth of cultural policies being established, and in the paradigms that support their goals. For now, these changes are more a question of analysing the issue and the form of policies, rather than modifying the content. One might formulate a hypothesis about a link between the structure and content. Therefore, the professionalization of these policies, an extension of financial resources and the territories in which they are implemented have direct effects on cultural offerings. But such effects suppose greater historical distance than the period of a few years that we now have. These two reasons for caution do not alter our confidence in our main hypothesis: that of growing territorialization of cultural policies. The analysis has emphasized the presence of a global-local tandem. France and Québec pursue common objectives which local particularities 'territorialize'.

First of all, despite contextual divergences unique to France and Québec, the objectives pursued through municipal reforms and the cultural sector are identical. From this angle, the differences between France and Québec are diminished, and the macronational distinctions become relative.

Second, the reformed municipal territories have affected local cultural practices in a similar fashion. Nonetheless, the application of these practices reveals each local territory's identity. The territorial particularities become central to the evolution of the municipal cultural sector. 
Finally, in both France and Québec, the restructured local territories define the municipal cultural sector. The territory actually appropriates the cultural domain. More than ever, culture constitutes a subject for public action which varies as a function of its territory. Local territory becomes the crucial space of public cultural policies.

However, a re-evaluation of 'public action territories' is consistent with a refusal to believe in a decline in importance of national policies. This is in no way a case of the communicating vessels effect. The state level continues to weigh in on sectoral choices. Yet it is the way the state intervenes that is evolving. In our analysis, the state, while maintaining its presence, becomes 'territorially contingent'. It is a failure to understand this new dialectic which has led the advocates of state disengagement astray (Peters, 1993; Leca, 1994). This circumstance has a direct impact on the comparison. Certainly, the phenomenon of convergence is apparent again in the varied territorial implementation of national policies. While these remain (constitutionally and substantially) different, it is their very coherence which becomes subject to an examination in terms of territorial plurality. Thus, this comparative study becomes naturally more relevant because each of the systems turns out to be more open to internal variations. The situation also becomes more complex because, by taking account of public policy, it then becomes necessary to study the 'plasticity' of its implementation in a number of national and local contexts. Finally, this leads us to relativize the distinctions between state models and overall ideologies of cultural policies, and to re-evaluate the spatial modalities, sociological depth and 'practical ideologies' of cultural action.

We have offered an alternative explanatory model of the links between a change in scale and public policies. This model, using culture as an example, selected a field where urban specialists rarely roam, though they recognize the importance of such a sector. Henceforth, the same type of demonstration needs to be employed in other more typical domains of metropolitan affairs: transport, social services and economic development. In these sectors we will undoubtedly be able to identify the components of a similar transformation of reality, and of analytical tools.

Sandra Breux (sandra.breux@ucs.inrs.ca) and Jean-Pierre Collin (jeanpierre.collin@ucs.inrs.ca), Institut National de la Recherche Scientifique, Centre Urbanisation, Culture et Société (INRS-UCS), 385 rue Sherbrooke Est, Montréal, Québec H2X 1E3, Canada, and Emmanuel Négrier (negrier@univ-montp1.fr), CNRS, Centre d'Études Politiques de l'Europe Latine (CEPEL), Université de Montpellier, 39 rue de I'Université, Montpellier, Cedex 34060, France.

\section{References}

Andrew, C. (2003) Municipal restructuring, urban services, and the potential for the creation of transformative political spaces. In W. Clement and L. Vosko (eds.), Changing Canada: political economy as transformation, McGill-Queen's University Press, Montréal and Kingston.

Baraize, F. and E. Négrier (eds.) (2001) L'invention politique de l'agglomération. L'Harmattan, Paris.

Bassett, K., I. Smith, M. Banks and J. O'Connor (2005) Urban dilemmas of competition and cohesion in cultural policy. In N. Buck, I. Gordon, A. Harding and I. Turok (eds.), Changing cities. Rethinking urban, competitiveness, cohesion and governance, Palgrave Macmillan, New York.

Belley, S. (2004) L'apprentissage collectif dans l'action: le défi de la planification et de la coordination métropolitaines dans les agglomérations urbaines de Montréal et de Québec. Paper presented at the Conference 'La Gouvernance Métropolitaine, Recherche de Cohérence dans la Complexité', 17th Entretiens du Centre Jacques Cartier, Montréal, 7-8 October.

Benko, G. and A. Lipietz (eds.) (1992) Les régions qui gagnent: districts et réseaux, les nouveaux paradigmes de la géographie économique. Presses Universitaires de France, Paris. 
Boudreau, J.A. (2003) The politics of territorialization: regionalism, localism and other isms . . . the case of Montreal. Journal of Urban Affairs 25.2, 179-99.

Boudreau, J.A. and R. Keil (2004) Le discours sur la démocratie locale et la compétitivité métropolitaine, Le cas de Toronto. Paper presented at the Conference ' $\mathrm{La}$ Gouvernance Métropolitaine, Recherche de Cohérence dans la Complexité', 17th Entretiens du Centre Jacques Cartier, Montréal, 7-8 October.

Brenner, N. (2002) Decoding the newest 'Metropolitan regionalism' in the USA: a critical overview. Cities 19.1, 3-21.

Breux, S. (under the direction of J.-P. Collin) (2004) Réorganisation municipale et politiques publiques locales en matière culturelle au Québec: des liens de rétroaction? Groupe de Recherche sur l'Innovation Municipale (GRIM), INRSUrbanisation, Culture et Société, Montréal.

Clark, T.N. and R. Inglehart (1998) The new political culture: changing dynamics of support for the welfare state and other policies in postindustrial societies. In T.N. Clark and V. Hoffmann-Martinot (eds.), The new political culture, Westview Press, Boulder, CO.

CNFFL (Commission nationale sur les finances et la fiscalité locales) (1999) Pact 2000. Gouvernement du Québec, Québec.

Collin, J.-P. (2002) La réforme de l'organisation du secteur municipal au Québec: la fin ou le début d'un cycle? Organisations et territoires 11.3, 5-13.

Collin, J.-P. (with the collaboration of S. Breux, A. Mevellec and I. Perreault) (2004) Par delà la fusion des municipalités: des solutions administratives, politiques et fiscales. Essai sur la coopération intermunicipale. Paper presented at the Symposium 'Construire de Nouvelles Coopérations pour le Développement Territorial', 11th session of the Territorial Development Policy Committee, Organisation de Coopération et de Développement Économique (OCDE), Paris, 3 June.

Collin, J.-P, S. Breux and M. Rivard (2006) Metropolitanization and the re-scaling of metropolitan governance. The Canadian experience. Paper presented at the international workshop 'Governance and Spatial Discontinuities: Reterritorialization or a New Polarization of Metropolitan Spaces?' Montreal, 24 April.
Collin, J.-P. and M. Robertson (2005) The borough system of consolidated Montréal: revisiting urban governance in a composite metropolis. Journal of Urban Affairs 27.3, 307-30.

De Maillard, J. (2005) Les politiques de sécurité. Réorientations politiques et différenciations locales. Sciences de la Société 65, 105-22.

Drier, P., J. Mollenkopf and T. Swanstrom (eds.) (2001) Place matters: metropolitics for the 21st century. University Press of Kansas, Lawrence.

Duran, F. and J.-C. Thoenig (1996) La gestion publique de l'État territorial. Revue Française de Science Politique 46, 580623.

Faure, A. and E. Négrier (2001) Vers une nouvelle donne communautaire? In A. Faure and E. Négrier, La politique culturelle des agglomérations, La Documentation Française, Paris.

Goldsmith, M. (2001) Urban governance. In R. Paddison (ed.), Handbook of urban studies, Sage Publications, London.

Heinelt, H. and D. Kübler (eds.) (2005) Metropolitan governance: capacity, democracy, and the dynamics of place. Routledge, London.

Jouve, B. (2003) La gouvernance urbaine en question. Elsevier, Paris.

Jouve, B. and C. Lefèvre (eds.) (2002) Métropoles ingouvernables. Les villes européennes entre globalisation et décentralisation. Elsevier, Paris.

Keil, R., J.-A. Boudreau, P. Hamel and B. Jouve (2006) New state spaces in Canada: metropolitanization in Toronto and Montréal. Paper presented at the 36th Annual Meeting, Urban Affairs Association, Montréal, 22 April.

Kerrouche, É. (2005) L'impasse démocratique des intercommunalités françaises ou le lien manquant. In L. Bherer, J.-P. Collin, É. Kerrouche and J.Palard (eds.), Jeuxd'échelle et transformation del'État. Le gouvernement des territoires au Québec et en France, Presses de l'Université Laval, Québec.

Latendresse, A. (2004) La réforme municipale et la participation publique aux affaires urbaines montréalaises: rupture ou continuité? In B. Jouve and P. Booth (eds.), Démocraties métropolitaines, Presses de l’Université du Québec, Québec.

Leca, J. (1994) L'État creux. In B. Badie et al., La France au-delà du siècle, La Tour d'Aigues, DATAR/Editions de l'Aube. 
Le Galès, P. (2002) European cities: social conflicts and governance. Oxford University Press, New York and Toronto.

Léveillée, J. and J.-F. Léonard (2003) Les arrondissements de Montréal: une scène politique en émergence. Paper presented at the workshop 'Gestion Locale et

Démocratie Participative. Les Arrondissements dans les Grandes Villes du Québec', INRS-Urbanisation, Culture et Société, Montréal, 23 May.

MAMM (Ministère des Affaires municipales et de la Métropole) (2000) Changing the ways to better serve the public. Gouvernement du Québec, Québec.

Négrier, E. (2004a) Les échelles politiques. État, pouvoir local et territoire dans la construction de nouvelles institutions métropolitaines en France. Paper presented at the conference 'La Gouvernance Métropolitaine, Recherche de Cohérence dans la Complexité', 17th Entretiens Jacques Cartier, Montréal, 7-8 October.

Négrier, E. (2004b) L'agglomération change-telle la politique? Une application aux politiques culturelles. In R. Le Saout and F. Madoré (eds.), Les effets de l'intercommunalité, Presses Universitaires de Rennes, Rennes.

Négrier, E. (2005a) La question métropolitaine. Presses Universitaires de Grenoble, Grenoble.

Négrier, E. (2005b) Vers des régimes politiques métropolitains? In L. Bherer, J.-P. Collin, E. Kerrouche and J. Palard (eds.), Jeux d'échelle et transformation de l'État: Le gouvernement des territoires au Québec et en France, Les Presses de l'Université Laval, Québec, Canada.

Négrier, E. (2006) La culture dans

l'intercommunalité. In Ministère de la Culture, Les Musées de France, acteurs et leviers de développement dans la recomposition des territoires, Direction des Musées de France, Paris.

Ostrom, V., C. Tiebout and R. Warren (1961) The organisation of government in metropolitan areas: a theoretical inquiry. American Political Science Review 55, 83142.

Peters, G. (1993) Managing the hollow state. In K. Eliassen and J. Kooiman (eds.), Managing public organizations, Sage Publications, London.

Pierre, J. (ed.) (2000) Debating governance. Authority, steering and democracy, Oxford University Press, Oxford.
Pinson, G. (2002) Political government and governance: strategic planning and the reshaping of political capacity in Turin. International Journal of Urban and Regional Research 26.3, 477-93.

Pinson, G. (2005) Le territoire des politiques: entre alignement idéologique et déplacement des clivages. L'analyse des politiques urbaines françaises entre précédent britannique et détour italien. Sciences de la Société 65, 28-51.

Piraux, P. (1997) De la loi du 6 février 1992 à la loi du 4 février 1995. In Centre universitaire de recherches administratives et politiques de Picardie,

L'intercommunalité. Bilan et perspectives, Presses Universitaires de France, Paris.

Purcell, M. (2003) Citizenship and the right to the global city: reimagining the capitalist world order. International Journal of Urban and Regional Research 27.3, 564-90.

Research and Statistics Directorate (2004) Public expenditures on culture in Québec from 2001 to 2002.

Saint-Pierre, D. and J. Coutard (2002) La culture comme facteur de développement de la ville. Recension des écrits et des sites Internet. Direction de l'action stratégique, de la recherche et de la statistique. Ministère de la culture et des communications, Québec.

Savitch, H.V. and P. Kantor (2003) Urban strategies for a global era. American Behovioral Scientist 46.8, 1002-33.

Sellers, J. and V. Hoffman-Martinot (2006) Toward an agenda for the cross-national study of metropolitan governance. Paper presented at the 36th Annual Meeting, Urban Affairs Association, 22 April 2006, Montréal.

Task Force on Greater Montréal (1993) Montréal a city-region: efficient, prosperous and vibrant, international by vocation, at the service of its citizens. Gouvernement du Québec, Québec.

Thuriot, F. (1997) Action culturelle et intercommunalité. In Centre universitaire de recherches administratives et politiques de Picardie, L'intercommunalité. Bilan et perspectives, Presses Universitaires de France, Paris.

Vivre en Ville (2001) Vers des collectivités viables... mieux bâtir nos milieux de vie pour le XXIe siècle. Septentrion, Québec.

Wood, R. (1961) 1400 governments. Harvard University Press, Cambridge. 


\section{Résumé}

Etudier l'influence des territoires sur les politiques publiques constitue une orientation de recherche plutôt inhabituelle. Elle va même en sens inverse par rapport aux approches les plus courantes dans l'étude de l'action publique territoriale, celles-ci tendant davantage à examiner comment les politiques publiques affectent les territoires. Les réformes municipales qui ont lieu simultanément au Québec et en France depuis la fin des années 1990 offrent une excellente occasion de réfléchir à cette inversion de perspective. Ce travail a pour thème la culture et les politiques culturelles municipales. Il vise à définir et comprendre dans quelle mesure il existe, au Québec et en France, des liens de rétroaction entre la restructuration des municipalités et les décisions municipales en matière d'installations et d'activités culturelles et, plus généralement, l'intervention culturelle municipale en milieu urbain. Cette analyse comparative des cas français et québécois s'attache à la fois aux discours et aux réalisations. D'abord, sont observés les changements qui résultent aussi bien des réformes institutionnelles concernant la fourniture d'activités culturelles, que des budgets consacrés à la culture ou des politiques culturelles. La culture est ensuite envisagée comme vecteur de construction d'une nouvelle institution et d'un nouveau territoire au plan municipal. 